\title{
Brazil's Unified Health System (SUS) and Its Treatment for Transgender People
}

\author{
Juliana Perucchi, Brune Coelho Brandão, Cláudio Magno Gomes Berto, \\ Fernanda Deotti Rodrigues, Junior Augusto da Silva \\ Department of Psychology, Federal University of Juiz de Fora, Juiz de Fora, Brazil \\ Email: jperucchi@gmail.com
}

Received 7 May 2014; revised 2 June 2014; accepted 24 June 2014

Copyright (C) 2014 by authors and Scientific Research Publishing Inc.

This work is licensed under the Creative Commons Attribution International License (CC BY). http://creativecommons.org/licenses/by/4.0/

(c) (i) Open Access

\begin{abstract}
This present article was constructed from an empirical work of intervention-research in a support group for transgender people which worked at the Clínica de Psicologia Aplicada (CPA) [Applied Psychology Clinic] of the Universidade Federal de Juiz de Fora (UFJF), in Minas Gerais, Brazil. It aimed at analyzing psychosocial aspects of the interventions that such people made to their bodies, investigating process of health and sickness involved in these contexts. The analysis of the participants' reports of the support group identified itself with a deep relation between the construction of the bodies and subjectivities of travesty and transgender people belonging to the lower classes and the utilization of the Brazilian public health system, called Unified Health System (SUS). As results, it found that in Brazil, the travesty and transgender population is neglected when accessing the public health services, which causes many damages and, in some cases, irretrievable consequences to the health of these people. The treatment model in the public health system in Brazil concerning the travesty and transgender population is reductionist and precarious, considering health only under the biological view and disregarding the complexity of this phenomenon. This way, SUS neglects the psychic losses that transgender brings related to their bodies, something which contradicts the broad health concept defined by the World Health Organization (WHO).
\end{abstract}

\section{Keywords}

Health, Trangender, Public Health System

\section{Introduction}

This present article was constructed from an empirical work of intervention-research in a support group for transgender people which worked at the Clínica de Psicologia Aplicada (CPA) [Applied Psychology Clinic] of 
the Universidade Federal de Juiz de Fora (UFJF), in Minas Gerais, Brazil. This work is part of a research project entitled "Gender, sex and transsexual travesty: abjections and becomings in the urban contexts of Minas Gerais", funded by the Fundação de Amparo à Pesquisa do Estado de Minas Gerais (FAPEMIG) [Minas Gerais Research Foundation]. Unfolded from a work of a broader research in association with the Universidade Federal de Santa Catarina (UFSC) and with the Universidade Federal de Pernambuco (UFPE) which aimed at problematizing the production of the contemporary subjectivities focusing on the sexualities meant to be deviant, in dissonance with the heteronorm. In this sense, it aimed at investigating the constitution of the body, under the vision of the relation sex-gender-body, from the narratives produced by travesties and transgender people, as well as analyzing psychosocial aspects of the interventions that such people made to their bodies, investigating process of health and sickness involved in these contexts.

The study of the bodies of travesty and transgender people, in a broader way, allows recognizing everyday difficulties lived by these people. While gay people, lesbians and bisexuals find somehow some support in Psychological Counseling and in Social Service, the position of a bigger subjectivity lived by transgender it is classified yet as a psychopathological disturbance, being presented in international manuals of mental diseases such as the DSM-IV (Diagnostic and Statistical Manual of Mental Disorders). It is known as transgender people those individuals who do not identify themselves with the gender they were designated when they were born and because of that they look for promoting modifications on their bodies through their lifetime, aiming at transforming them as closer as they can, aesthetically speaking, to the gender to what they identify themselves. Thus, they end up constructing the materiality of the gender on their bodies (Butler, 1993), turning them, this way, intelligible under the society patterns.

The analysis of the participants' reports of the support group identified itself with a deep relation between the construction of the bodies and subjectivities of travesty and transgender people belonging to the lower classes and the utilization of the Brazilian public health system, called Unified Health System (SUS). It is through SUS which is accomplished the surgical process of reassignment of gender, also known as transgender surgery process, through the accredited by the Ministry of Health of Brazil, having in mind that this kind of procedure is restricted to the public health system. SUS has the Brazilian federal government as the main supporter, which divides the outgoings and attributions with the states and the municipalities. SUS has a premise for its operation the warranty for the whole access to the health system, considering all the bio-psychosocial aspects of the population, in a universal way, that is, all the citizens of the country has equal rights to access the service, which foresees an equal treatment to all the Brazilian population. However, Brazilian studies (Lionço, 2008; Lionço, 2009; Arán \& Murta, 2009; Arán, Murta, \& Lionço, 2009; Almeida \& Murta, 2013) notice that when analyzing the reality of the access of the travesty and transgender population in Brazil to the services of health assistance it is noticed that the public health services in the country are focused for the heterosexual population and based on the heteronormativity which neglect the specific health needs of the Lesbians, Gays, Bissexuals and Transgenders-LGBT (Borges \& Souza, 2012), mainly in what refers to the travesty and transgender population.

The health of this population has been debated in Brazil by the Ministry of Health. In August, 2008 the country obtained a relevant advance with the approval of the Administrative Rule n. 1.707 and n. 1.457 which establish, in the scope of SUS, the transgender process, establishing technical and ethical guidelines and for this axis of attention in health. Although, even in a first moment the establishment of this legislation can seem an unquestionable gain for this population, it is still worth mentioning that:

The transgender process comprises a set of strategies of attention to health involved in the process of transformation of the sexual features that some transgender individuals have to overcome in certain moment of their lives. Therefore it is not about the establishment of the directions for the integral attention in the strict sense, but of those necessary actions to the warranty of the right to health circumscribed to the passage for the social living in a gender in disagreement with the gender from birth (Lionço, 2009: p. 44).

Such researches show how the care concerning the transgender population is still neglected, in what refers to the full and whole access to health. It can be realized that, frequently, there is a lack of a minimum preparation of the staffs to admit those individuals in the public health services and to deal with their specific requests in health, as it seems to be happening in arising situations of complications with the use of industrial silicone or because of the inappropriate use of hormones (Borges \& Souza, 2012). It is known that such attitudes are taken because of the deep dissatisfaction of the transgender about their bodies and that nowadays are perfectly viable from the biotechnical and scientific point of view. In this sense, the assistance is injured due to the prevalence of the reductionist conception that health professionals still have, focusing only on the illness process (Dalmolin et 
al., 2011), not considering the importance of information practices and of prevention in health, focused on the quality of life and for the welfare of a certain segment of the population.

Through the analysis of the participant's reports of the support group we intend to problematize how transgender people have their rights violated by the Brazilian government whose constitutional right should be to preserve the whole access to health through SUS, but whose programmatic vulnerability in front of the public health system of the country ends up putting them in an adverse reality because the public health system is characterized by its lack and inefficiency of policies focused on this population.

\section{Methodology}

The meetings of the support group for the travesty and transgender people occur fortnightly in the Applied Psychology Center of the Universidade Federal de Juiz de Fora having in every meeting the length of one hour and thirty minutes. All the meetings are filmed with the authorization of the participants, signed under the Written Informed Consent (WIC). This present study was developed from the analysis of the speeches taken from the accomplished meetings during a whole semester, having the films and the transcriptions of them as an analytical corpus.

It started from the theoretical-methodological referential of the Michel Foucault's Discourse Analysis (2009) to analyze the narratives of these travesty and transgender individuals, mostly regarding to the psychosocial process in health which involves such individuals in their relation with the public health system in Brazil. Looking for identifying the speech formations and the power relations/knowledge which (re)produce themselves and go through such processes.

\section{Results and Discussion}

From the analysis of the reports of the participants of the meetings accomplished in the support group, it can be noticed that one of the most significant complaints is related to the precarious treatment by part of the multi professional staff. The non-utilization of the social name ${ }^{1}$, that is, the name by which the travesty or transgender person wishes to be known is the first recurrent element during the reception provided by the accredited staff by the Ministry of Health in Brazil. Even having a Federal Administrative Rule (n. 1820, August 13th, 2009) which defends the use of the social name, its professionals do not respect it or they do not know it. This Administrative Rule which refers to the rights and duties of the users of the public health service, rules that the SUS card (user's identification document, necessary for the access to the services of the health system network) must have the social name of travesty and transgender people, not mentioning anything about their birth name. According to this document:

Single paragraph. It is the person's right, in the health services network, having a treatment in a humanized, welcoming, free of any kind of bias, restriction or denial due to the age, race, color, ethnics, religion, sexual orientation, gender identity, social or economical conditions, health state, anomaly, pathology or deficiency, assuring him/her: I-identification by the civil name and surname, being compulsory the existence in every document of the user a place to register his/her social name, not depending on the civil registration and assuring the use of the name of his/her preference, not being identified by a number, name or illness code or any other disrespectful or prejudiced ways (Brazil, 2009).

However, it is recurrent in the support group the report by part of the users of the service of not having their social names respected when being under treatment in the public hospital of their cities. In the words of a transgender man who participates in the group:

[...] I went to the Santos Dumont hospital to do X-rays (...) I took the SUS card with me, I asked them to be called by my social name. And they called me: “And where is Jane Doe?” And I started explaining and explaining. The hospital security guard was looking at my documents and at the time he called me I was going to the medical room. She (the doctor) called my name: "Jane Doe”. So I talked to the head nurse: "The thing is: I want to be called John. I gave my data to her and I talked to her how I wanted to be called and she kept on asking for 'Jane Doe'. She was making me feel as a fool.” (John, FtM transgender)

Another informant of the group states that:

\footnotetext{
${ }^{1}$ Social name refers to the name used by transgender people in their social relationships.
} 
"We already have the SUS social card, but there are people [from the staff of the accredited hospitals] which are not respecting the social card. Calling us by the registration name ${ }^{2}$." (Mary, MfF transgender).

Besides the bad training of the professionals, situations like that still occur because, in Brazil, even when the person has already undergone the genital reconstruction surgery, it is necessary that he/she starts a judicial proceeding for getting judicially the change of the name in the civil register for the social name with what he/she identifies him/herself. Thus, when marking a medical consultation in the public health network, besides having the SUS card in hands, the person must take their civil register documents (identification card) what makes explicit the incongruity of the register name with the image of the transgender person. Such request culminates in situations of discrimination and in the lack of humanization of the welcoming to the user, considering the specificities of the requests of the transgender people.

Besides, participants of the group brought in their reports the lack of specialized professionals like endocrinologists, psychiatrists, gynecologists, urologists and psychologists in the board of high complexity clinical staffs. In Brazil, there are only four specialized centers to treat transgender people, including psychological, hormonal and psychiatric monitoring, besides the accomplishment of surgical proceedings. Such services are available for the accomplishment of the proceedings for the Transgender Process, according to the Annex IV of the Administrative Rule of the Ministry of Health number 457, August 19th, 2008. They are: Hospital de Clínicas de Porto Alegre-Universidade Federal do Rio Grande do Sul-Porto Alegre/RS; Hospital Universitário Pedro Ernesto (HUPE) —Universidade Estadual do Rio de Janeiro—-Rio de Janeiro/RJ; Fundação Faculdade de Medicina HCFMUSP Instituto de Psiquiatria—Fundação Faculdade de Medicina MECMPAS—São Paulo/SP; Hospital das Clínicas da Universidade Federal de Goiás—Goiânia/GO.

However, even in these specialized centers, the treatments are not integrated, not fulfilling their own SUS guidelines when offering only part of the services recommended by the current legislation. Due to this lack of integrality and/or with this difficulty to have access to the services-for too few Brazilian municipalities offer this modality of specialized care-transgender people occupy a position of a bigger vulnerability in front of the risk of self-medication and the inadequate use (and without any specialized monitoring) of hormones and the corporal insertion of silicone. A negligence of the public health services in Brazil which puts this segment of the population in a risk position because of the use of substances and clandestine procedures which can bring irretrievable damages to health or even leading them to death. This speech excerpt taken from the participants of the support group highlights the gravity of the problem:

“They should create a campaign to guide the girls and the boys, whether transgender or travesty people, informing about the use [of hormones] and also offering professionals to give the prescriptions and to make the necessary exams because we don't have it. There isn't any professional inside SUS who offers this treatment." "With this [lack of health professionals] the person starts taking [hormone] at his/her own risk, and he/she keeps taking it without medical monitoring."

In front of reports like these, commonly enunciated in the everyday life of travesty and transgender people, it becomes indispensable to reflect upon the main challenges for the management of public health policies, for it really gets to accomplish the needs of this population in the integrality of the Brazilian Unified Health System. It is fundamental, however, to rethink the place of vulnerability in what it is fated the travesty and transgender citizen in the public health services in Brazil. A system which is a model of attention that ends up putting those people in conditions of a greater vulnerability, emphasizing even more the health risks for this population.

According to what Arán and Murta (2009) stated, transgender people who come to the health services, most of the times, find themselves in a situation of extreme vulnerability of many fields-psychic, physical and social—considering that the public health politicians should not only provide them with a necessary treatment during the transgender process, but mainly cooperate for the construction of an integrated network of services focused to the social inclusion of those people, which goes far beyond the medical proceedings and exclusively surgical. To that extent, it is going to be through the professional capacity of the interdisciplinary staff-that one which is going to welcome this individuals and conduct them through their treatment-through institutional measures of humanization and integrality in health, focused on the reception and care, it is going to be the way to guarantee a qualified assistance, free of discrimination and prejudice.

\footnotetext{
${ }^{2}$ Registration name refers to the name that is registered in people's civil documents after they were born.
} 


\section{Conclusion}

The reports highlighted in this article enunciate preliminarily the reality of the health needs of travesty and transgender people of the state of Minas Gerais, in Brazil and it corroborates with the results of studies accomplished nationally which accuses the unstableness of the health assistance network of this population in Brazil. Partial results of this present research point out that, in Brazil, the travesty and transgender population is neglected when accessing the public health services, which causes many damages and, in some cases, irretrievable consequences to the health of these people.

It can be noticed through the analysis of the reports which come from the support group accomplished in the scope of this research-intervention which, whether for the lack of a medical service based on the needs of corporal transformations or for a clinical treatment of high complexity which does not observe their own SUS guidelines, disrespecting the identity of the travesty and transgender people's gender who use this public service. Those people are in conditions of high vulnerability when they do the self-medication or they avoid doing other medical proceedings which are necessary for their physical, psychological and social welfare due to the embarrassment they have to overcome when being treated in the health system. The treatment model in the public health system in Brazil concerning the travesty and transgender population is reductionist and precarious, considering health only under the biological view and disregarding the complexity of this phenomenon. This way, SUS neglects the psychic losses which transgender bring related to their bodies, something which contradicts the broad health concept defined by the World Health Organization (WHO).

\section{References}

Almeida, G., \& Murta, D. (2013). Reflexões sobre a possibilidade da despatologização da transexualidade e a necessidade da assistência integral à saude de transexuais no Brasil. Sexualidad, Salud y Sociedad, 14, 380-407. (Recovered in March 20th, 2014, of SciElo (Scientific Electronic Library Online): www.scielo.br) http://dx.doi.org/10.1590/S1984-64872013000200017

Arán, M., \& Murta, D. (2009). Do diagnóstico de transtorno de identidade de gênero às redescrições da experiência da transexualidade: uma reflexão sobre gênero, tecnologia e saúde. Physis: Revista de Saúde Coletiva, 19, 15-41. (Recovered in March 20th, 2014, of SciElo (Scientific Electronic Library Online): www.scielo.br)

Arán, M., Murta, D., \& Lionço, T. (2009). Transexualidade e saúde pública no Brasil. Ciência \& Saúde Coletiva, 14, 11411149. (Recovered in March 20th, 2014, of SciElo (Scientific Electronic Library Online): www.scielo.br) http://dx.doi.org/10.1590/S1413-81232009000400020

Borges, C. A., \& Souza, M. (2012). Saúde das travestis: Um desafio para a enfermagem. In: XVI Simpósio de Ensino, Pesquisa e Extensão: Aprender e empreender na educação e na ciência do Centro Universitário Franciscano-UNIFRA, out.

Brazil (2008). Ministry of Health. Federal Administrative Rule Number 1.707. http://bvsms.saude.gov.br/bvs/saudelegis/gm/2008/prt1707_18_08_2008.html

Brazil (2008). Ministry of Health. Federal Administrative Rule Number 1.457.

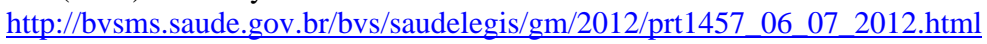

Brazil (2009). Ministry of Health. Federal Administrative Rule number 1.820. Recovered in March 20th, 2014, of http://www.brasilsus.com.br/legislacoes/gm/109086-1820.html?q

Butler, J. (1993) Bodies That Matter. Routledge: New York.

Dalmolin et al. (2011). Significados do conceito de saúde na perspectiva de Docentes da área da saúde. Esc Anna Nery, 15, 389-394. (Recovered in March 20th, 2014, of SciElo (Scientific Electronic Library Online): www.scielo.br)

Foucault, M. (2009). A arqueologia do saber (7th ed.). Rio de Janeiro: Forense Universitária.

Lionço, T. (2008). Que direito à saúde para a população GLBT? Considerando direitos humanos, sexuais e reprodutivos em busca da integralidade e da equidade. Saúde e Sociedade São Paulo, 17, 11-21. (Recovered in March 20th, 2014, of SciElo (Scientific Electronic Library Online): www.scielo.br)

Lionço, T. (2009). Atenção integral à saúde e diversidade sexual no Processo Transexualizador do SUS: avanços, impasses, desafios. Physis: Revista de Saúde Coletiva, 19, 43-63. (Recovered in March 20th, 2014, of SciElo (Scientific Electronic Library Online): www.scielo.br) 
Scientific Research Publishing (SCIRP) is one of the largest Open Access journal publishers. It is currently publishing more than 200 open access, online, peer-reviewed journals covering a wide range of academic disciplines. SCIRP serves the worldwide academic communities and contributes to the progress and application of science with its publication.

Other selected journals from SCIRP are listed as below. Submit your manuscript to us via either submit@scirp.org or Online Submission Portal.
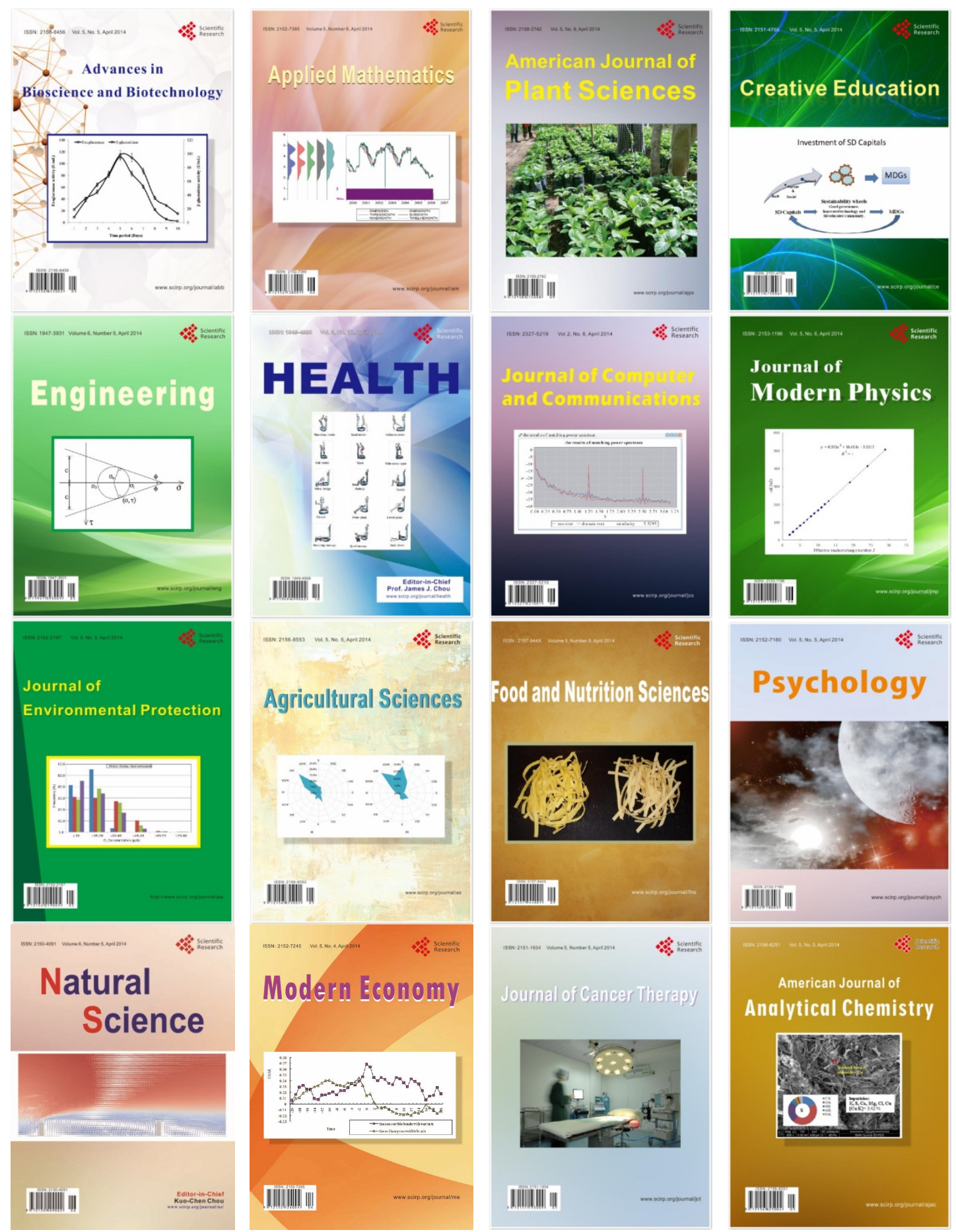